\title{
PENGUJIAN KUALITAS KELAYAKAN PERANGKAT LUNAK DENGAN PENERAPANPERANCANGAN MODEL RAPID APPLICATION DEVELOPMENT
}

\author{
Hari Toha Hidayat \\ Politeknik Negeri Lhokseumawe \\ e-mail: haritoha@pnl.ac.id
}

\begin{abstract}
Building a quality software is not easy. Many things to consider in making a quality software. The more qualified a software or app will be the more expensive the sale price. Quality software is not just looking for profit but the quality of the quality and quantity that has become a guarantee of the applications offered. Making a quality software always pay attention to the needs of its users, so as to provide solutions to the problems faced by its users. In addition, a quality application always through the stages - testing stages are not short so that really - guarantee the quality of its products. The value obtained from the test for completeness of the feature obtained the smallest standard error value of 0.008 and the highest error of 0.058 . For variable ease of use with the smallest standard error 0.013 and highest 0.063 . The last variable tested is flexibility with the smallest error value 0.015 and highest 0.035 . Based on the research that has been done it can be concluded that the making of school accounting information system operational costs (SIA BOS) declared feasible to be used by the user.
\end{abstract}

Keywords: software, variables, applications, quality

\begin{abstract}
ABSTRAK
Membangun suatu perangkat lunak yang berkualitas tidaklah mudah. Banyak hal yang harus diperhatikan dalam membuat suatu perangkat lunak yang berkualitas. Semakin berkualitas suatu perangkat lunak atau aplikasi maka akan semakin mahal harga yang dijual. Perangkat lunak yang berkualitas tidak hanya sekedar mencari keuntungan belaka akan tetapi mutu dari kualitas dan kuantitasnya yang sudah menjadi jaminan dari aplikasi yang ditawarkan. Pembuatan suatu perangkat lunak yang berkualitas selalu memperhatikan kebutuhan akan penggunanya, sehingga mampu memberikan solusi dari permasalahan yang dihadapi oleh para penggunanya. Selain itu, suatu aplikasi yang berkualitas selalu melalui tahapan - tahapan pengujian yang tidak singkat sehingga benar - benar menjamin akan kualitas produknya. Nilai yang diperoleh dari pengujian untuk kelengkapan fitur diperoleh nilai standard error terkecil yakni 0,008 dan error tertinggi yakni 0,058. Untuk variabel kemudahan penggunaan dengan standar error terkecil 0,013 dan tertinggi 0,063. Variabel yang terakhir diuji yakni fleksibilitas dengan nilai error terkecil 0,015 dan tertinggi 0,035. Berdasarkan penelitian yang sudah dilakukan maka dapat disimpulkan bahwa pada pembuatan sistem informasi akuntansi biaya operasional Sekolah (SIA BOS) dinyatakan layak digunakan oleh pengguna.
\end{abstract}

Kata kunci: perangkat lunak, variabel, aplikasi, kualitas

\section{PENDAHULUAN}

Pembuatan suatu perangkat lunak tidaklah mudah. Penjualan berbagai perangkat lunak sudah sangat menjamur ditengah masyarakat. Bahkan penjualan perangkat lunak bukanlah sesuatu hal yang baru.
Masyarakat saat ini sudah mulai menerima keberadaan penggunaan aplikasi dalam setiap kegiatan. Sebagai tambahan, masyarakat sudah mulai akan sadarnya manfaat yang begitu besar dengan keberadaan perangkat lunak yang mampu membantu pekerjaan dalam segala hal. 
Menjamurnya penjualan perangkat lunak (software) ditengah masyarakat juga perlu diantisipasi banyaknya perangkat lunak yang tidak berkualitas. Akibat dari suatu perangkat lunak yang tidak berkualitas menyebabkan tidak mampu memberikan penyelesaian dari masalah yang dihadapi oleh pengguna. Akhirnya perangkat lunak itu hanya menjadi sampah dalam komputer ataupun laptop dari pengguna.

Membangun suatu perangkat lunak yang berkualitas tidaklah mudah. Banyak hal yang harus diperhatikan dalam membuat suatu perangkat lunak yang berkualitas. Semakin berkualitas suatu perangkat lunak atau aplikasi maka akan semakin mahal harga yang dijual. Perangkat lunak yang berkualitas tidak hanya sekedar mencari keuntungan belaka akan tetapi mutu dari kualitas dan kuantitasnya yang sudah menjadi jaminan dari aplikasi yang ditawarkan.

Banyak perangkat lunak dengan harga yang murah dengan mudah didapatkan, akan tetapi aplikasi yang dijual tidak terdapat jaminan akan mutu kualitas dan kuantitasnya lebih baik dari suatu aplikasi dengan harga yang mahal. Terkadang aplikasi yang dijual dengan harga yang murah hanya sekedar mencari keuntungan saja.

Pembuatan suatu perangkat lunak yang berkualitas selalu memperhatikan kebutuhan akan penggunanya, sehingga mampu memberikan solusi dari permasalahan yang di hadapi oleh para penggunanya (Baharudin, 2015). Selain itu, suatu aplikasi yang berkualitas selalu melalui tahapan - tahapan pengujian yang tidak singkat sehingga benar benar menjamin akan kualitas produknya.

Adapun tahapan - tahapan untuk pembuatan perangkat lunak yang berkualitas dimulai dari pemilihan metode pengembangan perangkat lunak. Terdapat beberapa metode yang bisa digunakan dalam proses pengembangan perangkat lunak yakni metode sekuensial linier/ waterfall, model prototipe, model RAD, model spiral, fourth generation techniques (4GT) dan extreme programming (XP) model (Pressman, 2007). Akan tetapi, tidak semua metode tersebut bisa digunakan pada setiap proyek perangkat lunak.

Mubarok (2015) menyatakan bahwa kemajuan dan kecanggihan perangkat lunak yang maju dengan begitu pesatnya tentu diiringi dengan metode yang digunakan. Dalam pembuatan suatu perangkat lunak diperlukan suatu metode yang digunakan agar bisa menghasilkan perangkat lunak yang baik dan berkualitas. Kesalahan dalam pemilihan metode pengembangan bisa berakibat pada hasil perangkat lunak yang dikerjakan. Oleh karena itu, sangat diperlukan pemilihan metode pengembangan perangkat lunak dengan tepat.

\section{METODE}

Penelitian ini dilakukan dengan menggunakan metode pengujian sistem perangkat lunak berupa blackbox. Dimana pengujian blackbox ini dilakukan dalam internal tim. Adapun variabel penilaian yang dilakukan yakni: (1) kelengkapan fitur/ fungsi; (2) kemudahan penggunaan; dan fleksibilitas.

Model yang digunakan dalam penelitian ini untuk menghitung efektivitas dan efisiensi menggunakan simple random sampling. Adapun persamaan yang digunakan untuk menentukan ukuran/ jumlah sampel (n) untuk memperkirakan rata - rata populasi yakni:

$$
n=\frac{N}{\left(1+N \cdot e^{2}\right)} 1
$$

\section{Keterangan:}

$\mathrm{N}$ : ukuran sampel(orang)

$\mathrm{N}$ : ukuranpopulasi

e: persen kesalahan yang diinginkan atau ditolerir

Penelitian ini menggunakan uji validitas sistem untuk memperoleh hasil yang baik dalam model RAD didalam pengembangan perangkat lunak. Dalam uji validitas ini terdapat beberapa item yang diujikan yakni berupa nilai rata - rata (mean), standar deviasi dan standar error seperti yang digunakan peneliti sebelumnya (Setiya, 2016). Item uji validitas yang digunakan ini merupakan 
pengujian yang biasa digunakan untuk melihat tingkat validasi sistem. Adapun persamaan yang digunakan dalam menghitung nilai rata rata yakni:

$$
\mu=\frac{\sum x}{N} \ldots
$$

Persamaan yang digunakan dalam menghitung nilai standard deviasi yakni:

$$
\sigma=\sqrt{\frac{\sum(x-\mu)^{2}}{N}}
$$

Dan menghitung tingkat standard error yakni:

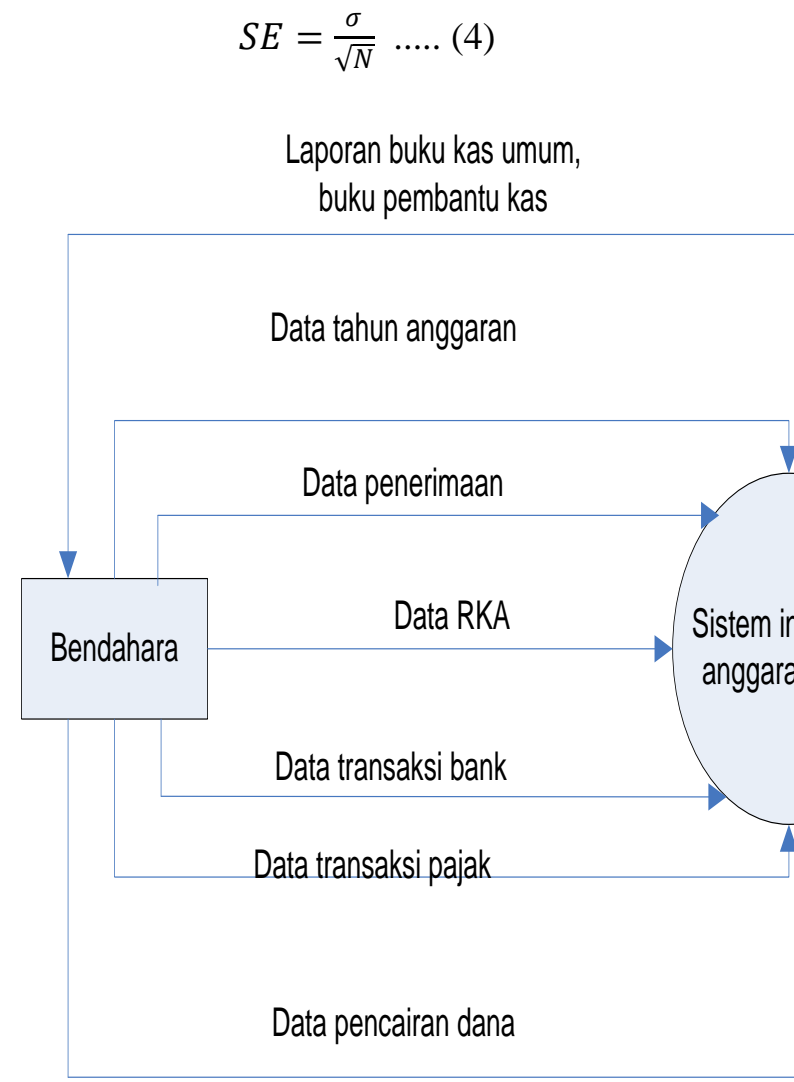

Keterangan:

$\sigma:$ standard deviasi

$\mathrm{N}$ : jumlah sampel

Pada penelitian ini perangkat lunak yang akan dibangun dan dilakukan pengujian adalah pembuatan sistem informasi akuntansi biaya operasional Sekolah (SIA BOS). Primawati \& Dewi (2013), model RAD (rapid application development) merupakan model proses pengembangan perangkat lunak secara linier sequential yang menekankan pada siklus pengembangan yang sangat singkat.

Gambar 1. Diagram konteks

Pendekatan model RAD menekankan cakupan: (1) pemodelan bisnis (Business Modelling). Aliran informasi diantaranya fungsi - fungsi bisnis dimodelkan dengan suatu cara untuk menjawab pertanyaan berikut: informasi apa yang mengendalikan suatu proses bisnis? Kemana informasi itu pergi? Siapa yang memprosesnya?; (2) pemodelan data (Data Modelling). Aliran informasi yang didefinisikan sebagai bagian dari fase pemodelan bisnis disaring kedalam serangkaian objek data yang dibutuhkan untuk menopang bisnis tersebut. Karakteristik/ atribut dari masing-masing objek diidentifikasi dan hubungan antara objek-objek tersebut didefinisikan; (3) pemodelan proses (Process Modelling). Aliran informasi yang didefinisikan dalam fase pemodelan dataditransformasikan untuk mencapai aliran informasi yang perlu bagi implementasi sebuah fungsi bisnis. Gambaran pemrosesan diciptakan untuk menambah, memodifikasi, 
menghapus atau mendapatkan kembali sebuah objek data; (4) pembuatan aplikasi (Application Generation). Selain menciptakan perangkat lunak dengan menggunakan bahasa pemrograman generasi ketiga yang konvensional, RAD lebih banyak memproses kerja untuk memakai lagi komponen program yang telah ada atau menciptakan komponen yang bisa dipakai lagi. Pada semua kasus, alat-alat bantu otomatis dipakai untuk memfasilitasi kontruksi perangkat lunak; dan (5) pengujian dan pergantian (Testing and turn over). Karena proses RAD menekankan pada pemakaian kembali, banyak komponen yang telah diuji. Hal ini mengurangi keseluruhan waktu pengujian. Tapi komponen baru harus diuji.

Perancangan sistem yang digunakan pada penelitian ini dibuat berbeda antara model RAD dengan model Prototipe. Hal ini disesuaikan dengan konsep perancangan dari masing-masing model. Bentuk perancangan sistem untuk model RAD seperti pada Gambar 1.

Perancangan yang dibuat pada penelitian ini selain sistem juga terdapat perancangan database. Perancangan database dikenal dengan entity relationship database (ERD). Pada perancangan ini dibuat sesuai dengan kebutuhan dari pengguna dalam pembuatan aplikasi sistem informasi akuntansi dana bantuan operasional sekolah (BOS). Terdapat 6 tabel utama yang dibutuhkan dalam aplikasi SIA BOS yakni tabel RKA (rencana kerja anggaran), tabel master penerimaan, tabel transaksi bank, tabel transaksi pajak, dan tabel tahun anggaran. Adapun perancangan database dalam ERD seperti pada Gambar 2.

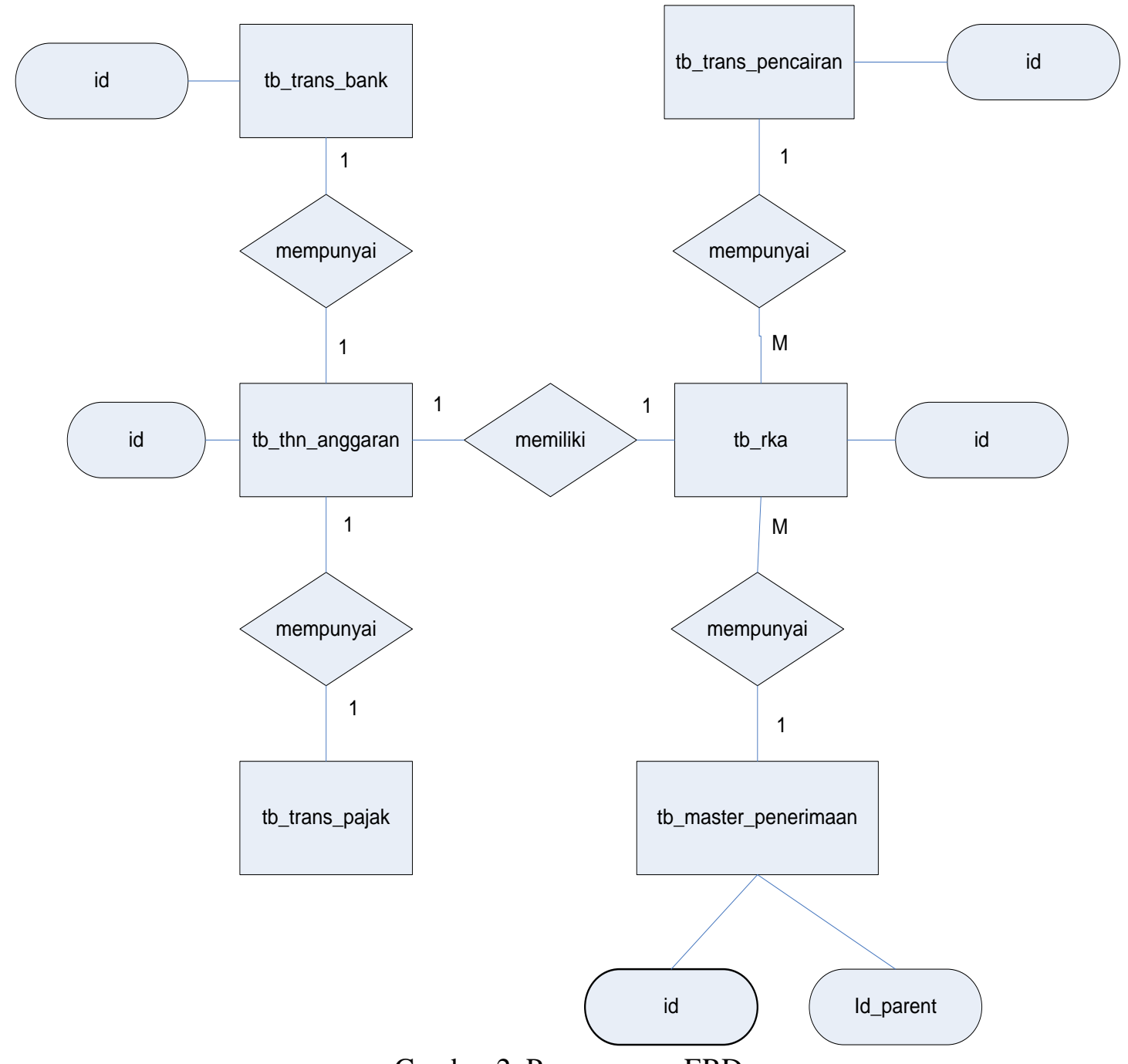

Gambar 2. Perancangan ERD 
HASIL

Penelitian ini melakukan pengujian terhadap sistem informasi akuntansi biaya operasional Sekolah (SIA BOS). Pengujian ini dilakukan untuk mengetahui tingkat kelayakan dari sistem yang telah dibuat sebelum digunakan oleh pengguna (user). Pengujian ini menjadi bahan evaluasi terhadap tim untuk mengetahui kekurangan dari sistem yang telah dibangun.

Pengujian sistem ini dilakukan oleh internal tim pengembang yang terdiri dari manajer, sistem analis, programmer dan teknikal support. Adapun penentuan jumlah sampel untuk melakukan pengujian ditentukan dengan cara jumlah ukuran populasi $(\mathrm{N})=25$, persentase kesalahan yang ditolerir $10 \%$ sehingga:

$$
\begin{aligned}
& n=\frac{N}{\left(1+N \cdot e^{2}\right)} 1 \ldots . .(1) \\
& n=\frac{25}{\left(1+25 \cdot(0,1)^{2}\right)} \\
& n=20
\end{aligned}
$$

Pengujian dilakukan dengan pemberian skor pada tiap varibel. Skor yang diberikan berada pada range 1 sampai dengan 4 . Dengan ketentuan: (1) nilai 1 = sangat tidak layak; (2) nilai 2 = kurang layak; (3) nilai 3 = layak; dan (4) nilai $4=$ sangat layak. Untuk Variabel Kelengkapan Fitur, berdasarkan hasil pengujian yang dilakukan oleh tim diperoleh nilai perhitungan deviasi dan nilai standar error pada Tabel 1.

Tabel 1. Nilai perhitungan standar deviasi dan standar eror pada variabel kelengkapan fitur

\begin{tabular}{cccc|cccc}
\hline $\begin{array}{c}\text { No. } \\
\text { Responden }\end{array}$ & $\mathrm{X}$ & Standard Deviasi & $\begin{array}{c}\text { Standar } \\
\text { error }\end{array}$ & $\begin{array}{c}\text { No. } \\
\text { Responden }\end{array}$ & $\mathrm{X}$ & Standard Deviasi & $\begin{array}{c}\text { Standar } \\
\text { error }\end{array}$ \\
\hline 1 & 4 & 0,190 & 0,043 & 11 & 3 & 0,034 & 0,008 \\
2 & 4 & 0,190 & 0,043 & 12 & 2 & 0,257 & 0,058 \\
3 & 4 & 0,190 & 0,043 & 13 & 2 & 0,257 & 0,058 \\
4 & 3 & 0,034 & 0,008 & 14 & 3 & 0,034 & 0,008 \\
5 & 3 & 0,034 & 0,008 & 15 & 3 & 0,034 & 0,008 \\
6 & 4 & 0,190 & 0,043 & 16 & 3 & 0,034 & 0,008 \\
7 & 3 & 0,034 & 0,008 & 17 & 4 & 0,190 & 0,043 \\
8 & 3 & 0,034 & 0,008 & 18 & 3 & 0,034 & 0,008 \\
9 & 3 & 0,034 & 0,008 & 19 & 3 & 0,034 & 0,008 \\
10 & 3 & 0,034 & 0,008 & 20 & 3 & 0,034 & 0,008 \\
\hline
\end{tabular}

Nilai rata - rata yang diperoleh:

$$
\begin{aligned}
& \mu=\frac{\sum x}{N} \ldots . . \\
& \mu=\frac{63}{20} \\
& \mu=3,15
\end{aligned}
$$

Berdasarkan perhitungan standard error diperoleh nilainya antara 0,008 sampai dengan 0,058. Jika dilihat dari hasil perhitungan standar error pada variabel kelengkapan fitur ini memiliki nilai error yang sangat rendah berada dibawah angka 1 . Hal ini menunjukkan bahwa kelengkapan fitur yang telah dibuat oleh tim pengembang sudah layak dan sesuai dengan keinginan dari pihak pengguna (user).

Untuk Variabel Kemudahan Pengguna, berdasarkan hasil pengujian yang dilakukan oleh tim diperoleh nilai perhitungan deviasi dan nilai standar error pada Tabel 2 . 
Tabel 2. Nilai perhitungan standar deviasi dan standar eror pada variabel kemudahan pengguna

\begin{tabular}{cccc|cccc}
\hline $\begin{array}{c}\text { No. } \\
\text { Responden }\end{array}$ & $\mathrm{X}$ & Standard Deviasi & $\begin{array}{c}\text { Standar } \\
\text { error }\end{array}$ & $\begin{array}{c}\text { No. } \\
\text { Responden }\end{array}$ & $\mathrm{X}$ & Standard Deviasi & $\begin{array}{c}\text { Standar } \\
\text { error }\end{array}$ \\
\hline 1 & 4 & 0,168 & 0,038 & 11 & 3 & 0,056 & 0,013 \\
2 & 4 & 0,168 & 0,038 & 12 & 2 & 0,280 & 0,063 \\
3 & 4 & 0,168 & 0,038 & 13 & 2 & 0,280 & 0,063 \\
4 & 4 & 0,168 & 0,038 & 14 & 3 & 0,056 & 0,013 \\
5 & 3 & 0,056 & 0,013 & 15 & 4 & 0,168 & 0,038 \\
6 & 4 & 0,168 & 0,038 & 16 & 3 & 0,056 & 0,013 \\
7 & 4 & 0,168 & 0,038 & 17 & 3 & 0,056 & 0,013 \\
8 & 4 & 0,168 & 0,038 & 18 & 3 & 0,056 & 0,013 \\
9 & 3 & 0,056 & 0,013 & 19 & 2 & 0,280 & 0,063 \\
10 & 3 & 0,056 & 0,013 & 20 & 3 & 0,056 & 0,013 \\
\hline
\end{tabular}

Nilai rata - rata yang diperoleh:

$$
\begin{aligned}
& \mu=\frac{\sum x}{N} \ldots . .(2) \\
& \mu=\frac{65}{20}=3,25
\end{aligned}
$$

Berdasarkan hasil perhitungan error dari variabel kemudahan penggunaan didapatkan nilai dari 0,013 sampai dengan 0,063 . Hal ini menunjukkan bahwa tingkat error yang didapatkan tidak berada diangka 1 , sehingga untuk variabel kemudahan penggunaan dinyatakan layak dan sesuai dengan kebutuhan dari pengguna.

Untuk Variabel Fleksibilitas, berdasarkan hasil pengujian yang dilakukan oleh tim diperoleh nilai perhitungan deviasi dan nilai standar error pada Tabel 3.

Tabel 3. Nilai perhitungan standar deviasi dan standar eror pada variabel fleksibilitas

\begin{tabular}{cccc|cccc}
\hline $\begin{array}{c}\text { No. } \\
\text { Responden }\end{array}$ & $\mathrm{X}$ & Standard Deviasi & $\begin{array}{c}\text { Standar } \\
\text { error }\end{array}$ & $\begin{array}{c}\text { No. } \\
\text { Responden }\end{array}$ & $\mathrm{X}$ & Standard Deviasi & $\begin{array}{c}\text { Standar } \\
\text { error }\end{array}$ \\
\hline 1 & 3 & 0,067 & 0,015 & 11 & 3 & 0,067 & 0,015 \\
2 & 3 & 0,067 & 0,015 & 12 & 3 & 0,067 & 0,015 \\
3 & 3 & 0,067 & 0,015 & 13 & 3 & 0,067 & 0,015 \\
4 & 3 & 0,067 & 0,015 & 14 & 4 & 0,157 & 0,035 \\
5 & 3 & 0,067 & 0,015 & 15 & 3 & 0,067 & 0,015 \\
6 & 4 & 0,157 & 0,035 & 16 & 4 & 0,157 & 0,035 \\
7 & 4 & 0,157 & 0,035 & 17 & 4 & 0,157 & 0,035 \\
8 & 3 & 0,067 & 0,015 & 18 & 3 & 0,067 & 0,015 \\
9 & 4 & 0,157 & 0,035 & 19 & 3 & 0,067 & 0,015 \\
10 & 3 & 0,067 & 0,015 & 20 & 3 & 0,067 & 0,015 \\
\hline
\end{tabular}

Nilai rata - rata yang diperoleh:

$$
\begin{aligned}
& \mu=\frac{\sum x}{N} \ldots . .(2) \\
& \mu=\frac{66}{20}=3,3
\end{aligned}
$$

Berdasarkan hasil standar error didapatkan nilai 0,015 dan 0,035 . Hal ini menunjukkan bahwa aplikasi yang dibangun sudah bersifat fleksibel. Hal ini menunjukkan bahwa aplikasi yang dibangun oleh tim mudah dilakukan maintenance karena bersifat fleksibel.

Aplikasi SIA BOS dalam penelitian ini telah dibuat dengan menggunakan bahasa pemrograman framework berbasis web. Pembuatan aplikasi SIA BOS ini telah 
didesain sesuai dengan permintaan dari pengguna dan berdasarkan analisis data yang diberikan oleh pengguna kepada peneliti.

Tampilan login seperti pada Gambar 4 ini dibuat berdasarkan hak pengguna. Dimana aplikasi ini terdapat dua pengguna utama yakni Kepala Sekolah MAN 1 Lhokseumawe dan bendahara Sekolah. Dimana akses yang diperoleh dari masing - masing berbeda menyesuaiakan dengan kebutuhan dan hak akses. Setelah para pengguna memasukkan username dan password maka aplikasi akan masuk ke menu utama SIA BOS seperti pada Gambar 3 .

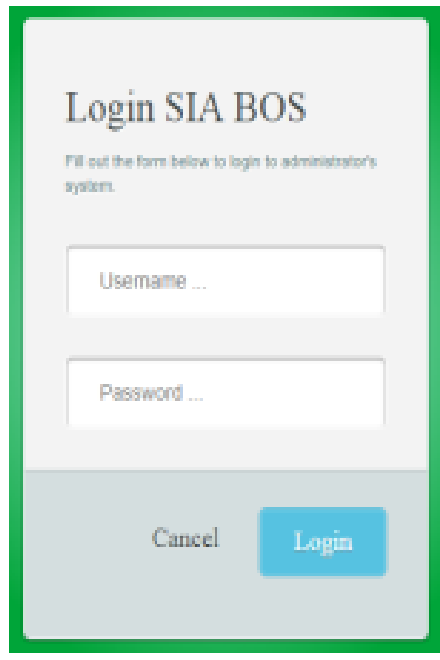

Gambar 3. Tampilan login
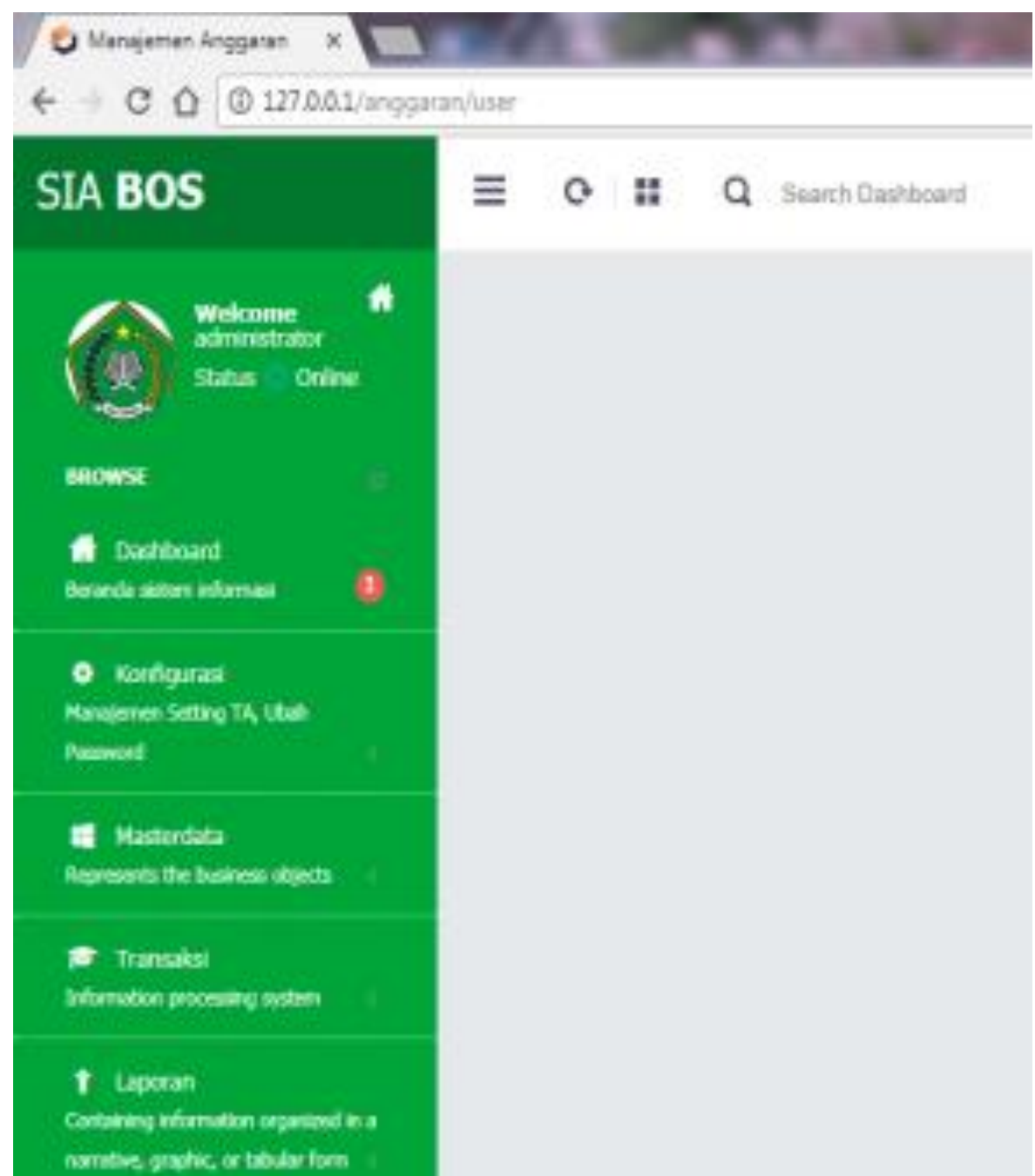

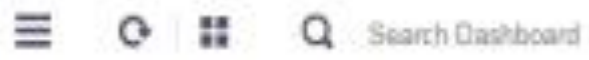

Gambar 4. Tampilan utama SIA BOS

Menu berikutnya selain tahun anggaran dalam SIA BOS juga terdapat menu data RKA seperti pada Gambar 5. 


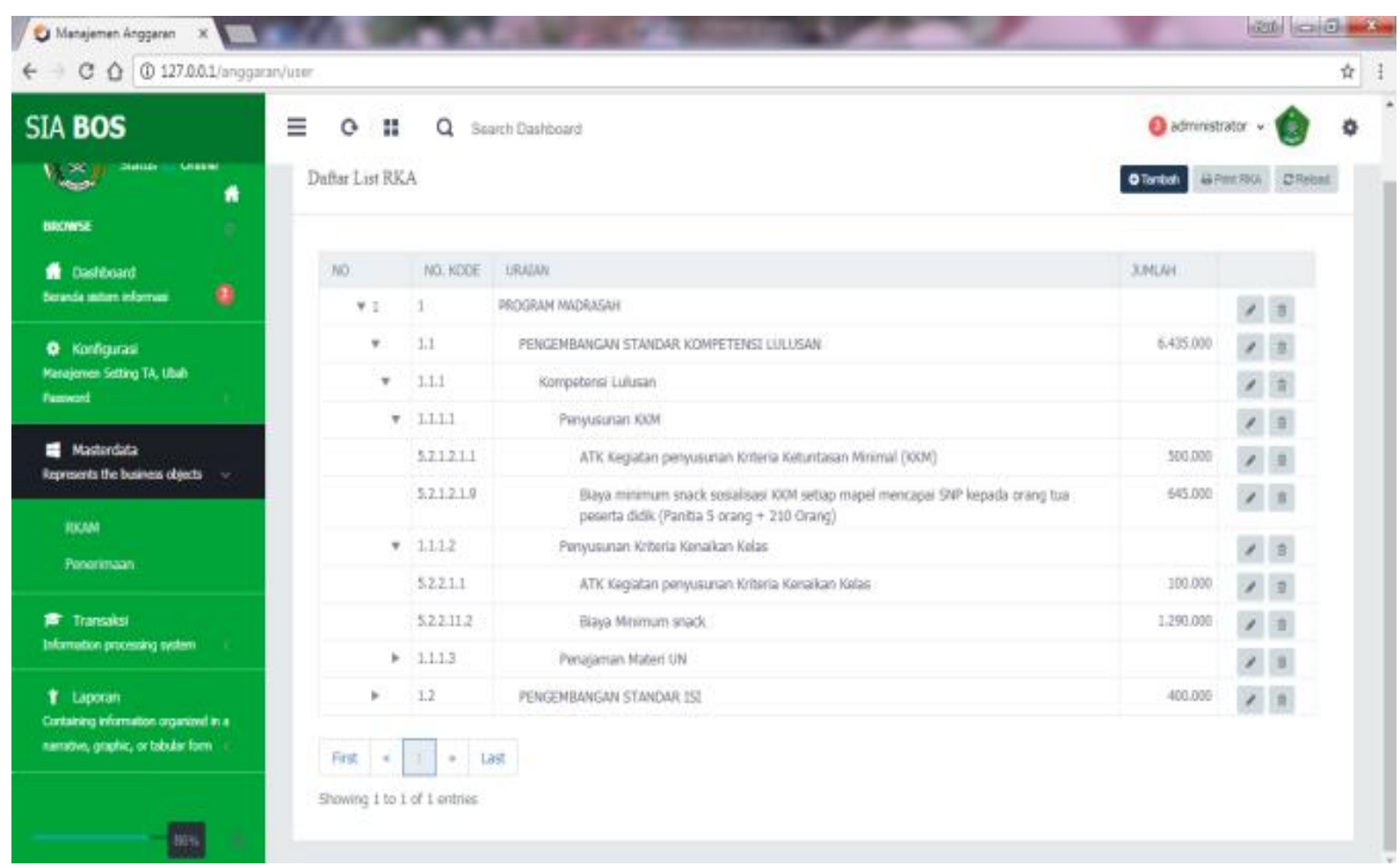

Gambar 5. Tampilan menu data RKA

Menu selanjutnya yang terdapat dalam aplikasi SIA BOS adalah transaksi pencairan dana BOS seperti pada Gambar 6.

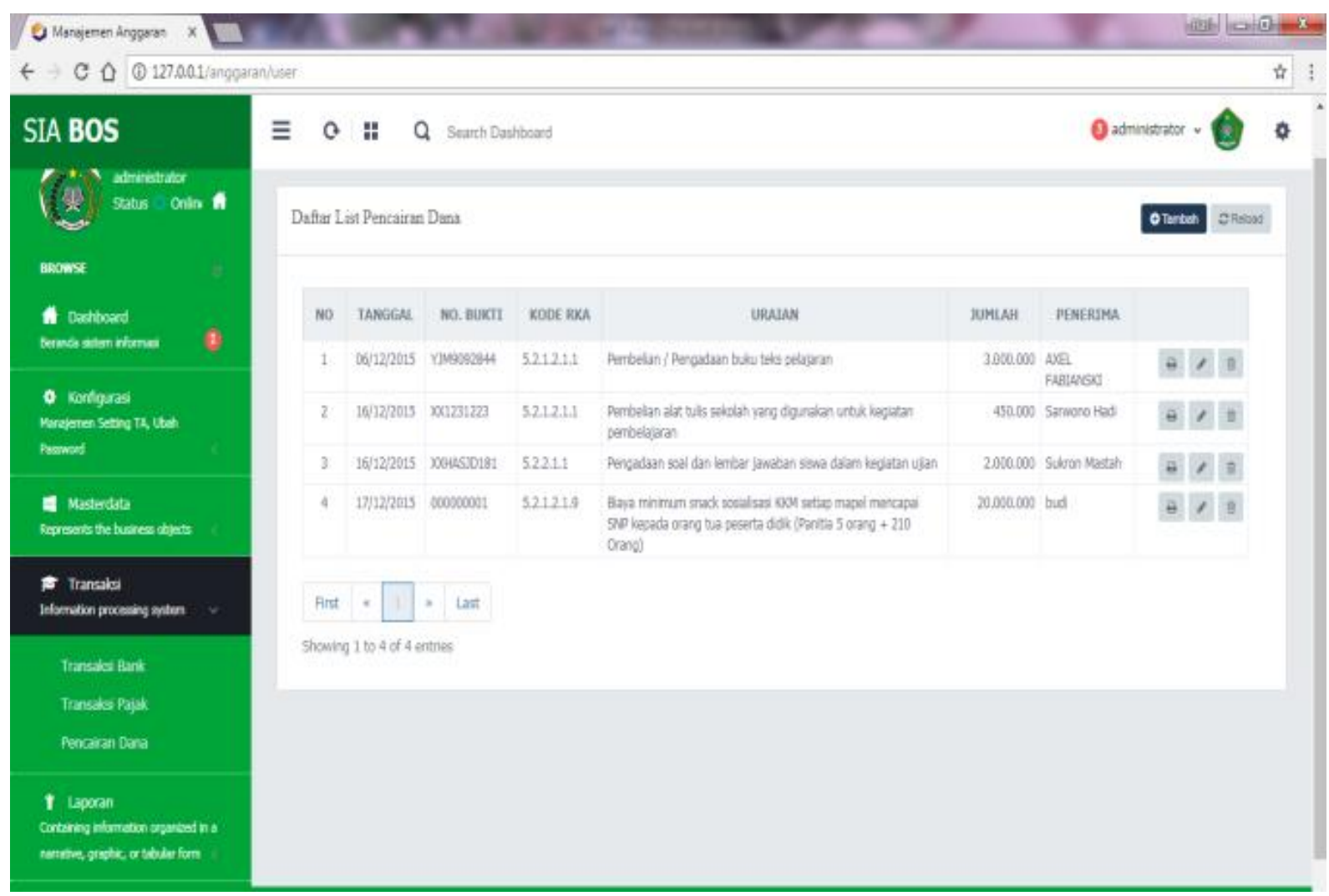

Gambar 6. Tampilan menu transaksi pencairan dana BOS 


\section{SIMPULAN}

Berdasarkan penelitian yang sudah dilakukan maka dapat disimpulkan bahwa pada pembuatan sistem informasi akuntansi biaya operasional Sekolah (SIA BOS) dinyatakan layak digunakan oleh pengguna hal ini berdasarkan hasil pengujian berupa kelengkapan fitur, kemudahan penggunaan dan fleksibilitas.

Nilai yang diperoleh dari pengujian untuk kelengkapan fitur diperoleh nilai standard error terkecil yakni 0,008 dan error tertinggi yakni 0,058 . Untuk variabel kemudahan penggunaan dengan standar error terkecil 0,013 dan tertinggi 0,063 . Variabel yang terakhir diuji yakni fleksibilitas dengan nilai error terkecil 0,015 dan tertinggi 0,035 .

\section{DAFTAR PUSTAKA}

Baharudin Yusuf dkk. 2015. Analisa Perbandingan Efisiensi Implementasi Arsitektur Sistem Berbasis MVVM dan Conventional. Diakses dari https://www.pens.ac.id/uploadta/downlo admk.php?id=1795 pada 20 Oktober 2017

Mubarok Farid, dkk. 2015. Perbandingan Antara Model RUP dengan Prototype dalam Aplikasi Penerimaan Siswa Baru Berbasis Web. Citec Journal, Vol.2 No.2, Februari - April 2015, ISSN: 2354-5771. Diakses dari ejournal.ikado.ac.id/index.php/teknika/a rticle/view/48/38 pada 17 April 2017

Pressman Roger S. 2007. Rekayasa Perangkat Lunak Pendekatan Praktisi (Buku sSatu), Edisi II, (diterjemahkan oleh: LN Harnaningrum), Andi, Yogyakarta

Primawati Alusyanti \& Dewi Mustari. 2013. Analisis Manajemen Proyek Perangkat Lunak Sistem Informasi Akuntansi Pada Biro Sistem Informasi PT.X. Journal of Information Systems, Volume 9, Issue2, October 2013.
Setiya Budi Darmawan dkk. 2016. Analisis Pemilihan Penerapan Proyek Metodologi Pengembangan Rekayasa Perangkat Lunak. TEKNIKA, Volume 5, Nomor 1, November 2016, ISSN: 2549-8037. Diakses dari ojs.amikom.ac.id/index.php/citec/article /download/368/348 pada 17 April 2017 